\title{
Oaks (Quercus spp.) parasitised by mistletoe Viscum album (Santalaceae) in Britain
}

\author{
John Box* \\ Telford, UK
}

*Corresponding author: John Box, email: john.box@knowlebox.co.uk

This pdf constitutes the Version of Record published on $11^{\text {th }}$ February 2019.

\begin{abstract}
Information on oaks Quercus spp. parasitised by Viscum album L. in Britain that was obtained in a comprehensive review of the literature and records with site visits from 1996 to 1998 has been updated during 2017 and 2018. Currently there are thirteen confirmed mistletoe-oaks in Britain. V. album parasitising Quercus spp. mainly occurs at locations in and around Herefordshire in the core of the current and past distribution of $V$. album in Britain. The results of this recent survey accord with the earlier review and with reports in the 19th and early 20th centuries suggesting that the population of between ten and twenty Quercus trees parasitised by $V$. album in Britain appears to be relatively stable over time with some losses of host trees and gains from the parasitism of new trees. Quercus robur $\mathrm{L}$. is the most frequent host amongst the existing mistletoe-oaks which also include 'red oaks' ( $Q$. rubra L., $Q$. coccinea Münchh. and $Q$. palustris Münchh.). The estimated ages of the existing Quercus hosts range from 30 to 400 years. The mistletoe-oaks are located in woodland, woodland edges, hedges, parkland, a garden, a churchyard and open countryside by a watercourse.
\end{abstract}

Keywords: parasitism; pedunculate oak; pin oak; red oak; scarlet oak; sessile oak.

\section{Introduction}

Viscum album parasitising Quercus robur and $Q$. petraea (Matt.) Liebl. is an uncommon association throughout Western Europe (Tubuef, 1923; Grazi \& Urech, 1983; pers. comm., Konrad Urech, August 2017). France appears to be the exception with mistletoe recorded on 390 indigenous oaks ( $Q$. robur \& $Q$. petraea) and on 463 'American oaks' ( $Q$. coccinea, $Q$. palustris, Q. rubra) (Frochot, Grazi \& Urech, 1994; Ramm et al., 2000; Urech, 2008). At many locations in France, either $V$. album has disappeared from the oak tree or the tree is no longer present and currently there are about 245 indigenous oak trees with $V$. album (pers. comm., Konrad Urech, August 2017).

In Britain, Quercus spp. have always been a rare host for $V$ album (Evelyn, 1664; Ray, 1677; Withering, 1796; Loudon, 1838; Bull, 1907; Tubuef, 1923; Nicholson, 1932; Perring, 1973). The current and historical status of Quercus with $V$. album in Britain was reported by Box (2000) based on a comprehensive survey from 1996 to 1998 involving the published literature, county floras, herbaria, the 
Biological Records Centre and local records centres, the County Recorders of the Botanical Society of Britain \& Ireland (BSBI) and site visits.

\section{Methods}

Additional information to that given in Box (2000) was sought in various ways and confirmed by visits to specific locations. Requests for information were circulated to environmental and biological records centres in Great Britain in August 2017 by the Association of Local Environmental Records Centres (ALERC) and to the BSBI County Recorders through the BSBI eNews in January 2018 (http://bsbi.org/wpcontent/uploads/dlm uploads/BSBI-eNews-January-2018.pdf). Wide circulation about this was achieved through the BSBI News \& Views blog (http://bsbipublicity.blogspot.com/2018/01/mistletoe-growing-on-oak.html) and via the BSBI Twitter account (https://twitter.com/BSBIbotany) during January 2018.

The original eleven Quercus trees with V. album recorded by Box (2000) and the additional trees identified by ALERC and the county botanical recorders were visited in winter months between October 2017 and December 2018 (in some cases more than once in different months). The presence or absence of $V$. album berries from a visual inspection using $12 \times 25$ binoculars determined if the plant was female (Fig. 1) or was assumed to be male (confirmation would have required a careful inspection of flowers). The girth of each of the additional Quercus trees supporting $V$. album was measured at $1.3 \mathrm{~m}$ above ground level and used to derive the diameter at breast height ( $\mathrm{dbh}$ ) from which the age of each tree was estimated taking into account the species, location and habitat (White, 1998, Table 1a).

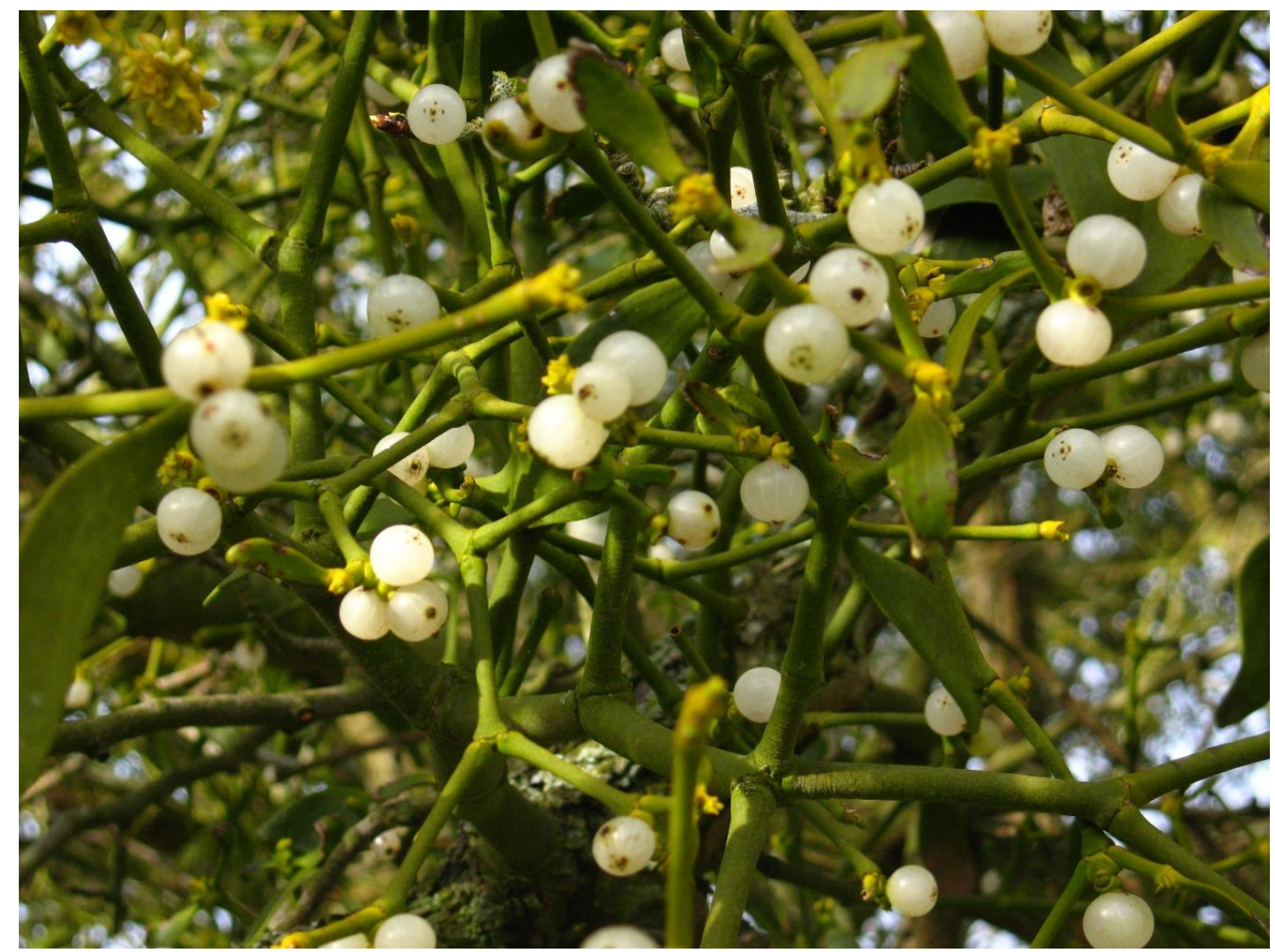

Figure 1. V. album with berries 


\section{Results}

The current status of the original eleven Quercus trees with V. album (Box, 2000) and four new mistletoe-oaks is set out in Table 1. $Q$. rubra is preferred to the synonym $Q$. borealis used in Box (2000). Full descriptions of the locations are not given below and the locations are ascribed to a nearby village or town and the relevant $10 \mathrm{~km}$ square (hectad) of the Ordnance Survey national grid.

Table 1. Current status of Quercus parasitised by V. album in 2017 and 2018

\begin{tabular}{|c|c|c|}
\hline $\begin{array}{l}\text { Location } \\
\text { Hectad } \\
\text { Watsonian vice } \\
\text { county }\end{array}$ & $\begin{array}{l}\text { Quercus } \\
\text { species }\end{array}$ & Summary description of $\mathrm{V}$. album \\
\hline $\begin{array}{l}\text { Brampton Bryan } \\
\text { SO } 37 \\
\text { Herefordshire (v.c. } \\
\text { 36) }\end{array}$ & $\begin{array}{l}Q . \\
\text { coccinea }\end{array}$ & $\begin{array}{l}\text { One female bunch at base of main branch } \\
\text { close to main trunk at around } 15 \mathrm{~m} \text { in } \\
\text { height in parkland tree (1996: dbh } 65 \mathrm{~cm} \text {, } \\
\text { estimated age } 90 \text { y). Originally recorded as } \\
\text { one bunch that was assumed to be male in } \\
\text { December } 1996 \text { and December } 1998 .\end{array}$ \\
\hline $\begin{array}{l}\text { Bredwardine } \\
\text { SO } 34 \\
\text { Herefordshire (v.c. } \\
\text { 36) }\end{array}$ & Q. robur & $\begin{array}{l}\text { Female bunches in four separate locations } \\
\text { on a branch and on the main trunk at } \\
\text { heights of } 9.5 \mathrm{~m} \text { to } 11 \mathrm{~m} \text { in hedgerow tree } \\
\text { (1996: dbh } 185 \mathrm{~cm} \text {, estimated age } 300-400 \\
\text { y). Originally recorded as two female } \\
\text { bunches in } 1996 \text {. }\end{array}$ \\
\hline $\begin{array}{l}\text { Brinsop } \\
\text { SO } 44 \\
\text { Herefordshire (v.c. } \\
\text { 36) }\end{array}$ & Q. robur & $\begin{array}{l}\text { Two female bunches on branches at around } \\
10 \mathrm{~m} \text { and } 15 \mathrm{~m} \text { in height on tree by } \\
\text { watercourse in open countryside (1996: dbh } \\
107 \mathrm{~cm} \text {, estimated age } 160-170 \mathrm{y}) \text {. }\end{array}$ \\
\hline $\begin{array}{l}\text { Deerfold } \\
\text { SO } 36 \\
\text { Herefordshire (v.c. } \\
\text { 36) }\end{array}$ & $\begin{array}{l}\text { Q. robur } \mathrm{x} \\
\text { Q. petraea }\end{array}$ & $\begin{array}{l}\text { The bunch recorded in December } 1996 \text { is no } \\
\text { longer present. There are two short mature } \\
\text { stems which show evidence of being cleanly } \\
\text { cut and at least three small, young growths } \\
\text { in the same location on the west side of the } \\
\text { western of the two upper trunks (1996: dbh } \\
142 \mathrm{~cm} \text {, estimated age } 190-260 \text { y). The } \\
\text { position is similar to that depicted by Bull } \\
(1869) \text {. }\end{array}$ \\
\hline $\begin{array}{l}\text { Eastnor } \\
\text { SO } 73 \\
\text { Herefordshire (v.c. } \\
\text { 36) }\end{array}$ & Q. robur & $\begin{array}{l}\text { Luxuriant growth of female plants on } \\
\text { branches and main trunk at around } 10 \mathrm{~m} \text { in } \\
\text { height on a woodland tree (1996: dbh } 85 \\
\mathrm{~cm} \text {, estimated age } 210-240 \mathrm{y}) \text {. }\end{array}$ \\
\hline $\begin{array}{l}\text { Frampton-on-Severn } \\
\text { SO } 70 \\
\text { West Gloucestershire } \\
\text { (v.c. 34) }\end{array}$ & Q. robur & $\begin{array}{l}\text { One female bunch with at least five } \\
\text { separate stems growing on main branch } \\
\text { close to trunk at around } 6 \mathrm{~m} \text { in height in a } \\
\text { hedgerow tree (1997: dbh } 146 \mathrm{~cm} \text {, } \\
\text { estimated age } 250-270 \mathrm{y} \text { ). }\end{array}$ \\
\hline
\end{tabular}




\begin{tabular}{|c|c|c|}
\hline $\begin{array}{l}\text { Great Malvern } \\
\text { SO } 74 \\
\text { Worcestershire (v.c. } \\
\text { 37) }\end{array}$ & Q. rubra & $\begin{array}{l}\text { Around } 14 \text { bunches (half female, half } \\
\text { assumed to be male) growing on branches } \\
\text { at heights from } 2 \mathrm{~m} \text { to the upper parts of a } \\
\text { mature hedgerow tree }(2017: \text { dbh } 80 \mathrm{~cm} \text {, } \\
\text { estimated age } 80-100 \mathrm{y}) \text {. }\end{array}$ \\
\hline $\begin{array}{l}\text { Gwehelog } \\
\text { SO } 30 \\
\text { Monmouthshire (v.c. } \\
\text { 35) }\end{array}$ & Q. robur & $\begin{array}{l}\text { One bunch assumed to be male growing on } \\
\text { main trunk at around } 10 \mathrm{~m} \text { in height at edge } \\
\text { of woodland }(1997: \mathrm{dbh} 97 \mathrm{~cm} \text {, estimated } \\
\text { age } 140-150 \mathrm{y}) \text {. }\end{array}$ \\
\hline $\begin{array}{l}\text { Huddington } \\
\text { SO } 95 \\
\text { Worcestershire (v.c. } \\
\text { 37) }\end{array}$ & Q. rubra & $\begin{array}{l}\text { Three female bunches growing on branches } \\
\text { at heights of around } 2 \mathrm{~m} \text { and } 3 \mathrm{~m} \text { in a } \\
\text { hedgerow tree (2017: dbh } 31 \mathrm{~cm} \text {, estimated } \\
\text { age } 30-40 \mathrm{y}) \text {. }\end{array}$ \\
\hline $\begin{array}{l}\text { Leintwardine } \\
\text { SO } 47 \\
\text { Herefordshire (v.c. } \\
\text { 36) }\end{array}$ & Q. rubra & $\begin{array}{l}\text { Four female bunches on separate branches } \\
\text { at heights of around } 2 \mathrm{~m} \text { to } 6 \mathrm{~m} \text {. Only one } \\
\text { female bunch was present in December } \\
1996 \text { on this churchyard tree (1996: dbh } 63 \\
\mathrm{~cm} \text {, estimated age } 90 \mathrm{y} \text { ). }\end{array}$ \\
\hline $\begin{array}{l}\text { Penallt } \\
\text { SO } 50 \\
\text { Monmouthshire (v.c. } \\
\text { 35) }\end{array}$ & Q. rubra & $\begin{array}{l}\text { One female bunch with multiple main stems } \\
\text { on two adjacent branches at a height of } \\
\text { around } 7 \mathrm{~m} \text { on woodland edge (2018: } \\
\text { estimated age } 60-70 \mathrm{y} \text { ). }\end{array}$ \\
\hline $\begin{array}{l}\text { Putley } \\
\text { SO } 63 \\
\text { Herefordshire (v.c. } \\
\text { 36) }\end{array}$ & Q. rubra & $\begin{array}{l}\text { Tree felled around } 2000 \text { because of disease } \\
\text { (pers. comm., Ray \& Elizabeth Hunter, } \\
\text { November 2017). }\end{array}$ \\
\hline $\begin{array}{l}\text { Sheffield } \\
\text { SK } 38 \\
\text { South-west Yorkshire } \\
\text { (v.c. 63) }\end{array}$ & Q. palustris & $\begin{array}{l}\text { One female bunch growing on top of branch } \\
\text { in angle with trunk at a height of around } 3 \\
\mathrm{~m} \text { in a park (2018: dbh } 26 \mathrm{~cm} \text {, estimated } \\
\text { age } 30 \mathrm{y} \text { ). }\end{array}$ \\
\hline $\begin{array}{l}\text { Stretton Sugwas } \\
\text { SO } 44 \\
\text { Herefordshire (v.c. } \\
\text { 36) }\end{array}$ & Q. robur & $\begin{array}{l}\text { Tree present. Branch with } V \text {. album was } \\
\text { sawn off prior to April } 2012 \text { (pers. comm., } \\
\text { Tony Titchen, April 2012) by power supply } \\
\text { company because of proximity to overhead } \\
\text { power lines (pers. comm., Richard Morgan- } \\
\text { Jones, November 2017). }\end{array}$ \\
\hline $\begin{array}{l}\text { Windsor } \\
\text { SU } 96 \\
\text { Berkshire (v.c. 22) }\end{array}$ & Q. rubra & $\begin{array}{l}\text { Three female bunches growing on branches } \\
\text { at around } 6 \mathrm{~m} \text { and } 10 \mathrm{~m} \text { in a park (1997: } \\
\text { dbh } 81 \mathrm{~cm} \text {, estimated age } 115 \text { y). Originally } \\
\text { recorded as one bunch assumed to be male } \\
\text { in January } 1997 \text { and November } 1998 \text {. }\end{array}$ \\
\hline
\end{tabular}

Additional locations and information concerning Quercus parasitised by $V$. album to that in Box (2000) are set out below in order of the Watsonian vice-counties. 


\section{Dorset (v.c. 9)}

Chalbury Dorset Environmental Records Centre (DERC) has a record from April 2014. This was determined in January 2018 to be on lime (Tilia sp.) and the record will be revised (pers. comms., Martin Rand and Robin Walls).

Shillingstone DERC has records from three separate locations from 2000 and 2016. These were checked in February 2018 and are either no longer present (2000 record) or are not on oak (2016 records) and the records will be revised (pers. comms., Carolyn Steele and Judith Crompton).

\section{South Hampshire (v.c. 11)}

Braishfield Hampshire Biodiversity Information Centre has a record from May 2012 "On Oak (Quercus robur) - several trees, east side of road". A site visit in January 2018 confirmed that tufts of atypical twigs were misidentified as V. album and the original record will be revised (pers. comm., Martin Rand).

\section{East Kent (v.c. 15)}

Boxley The BSBI Database and the Kent \& Medway Biological Records Centre have a record from March 2010 (pers. comm., Geoffrey Kitchener). The host tree was determined as field maple (Acer campestre) by inspection in February 2018 (John Box) and exchange of photographic evidence with the original recorder; the record in both databases will be revised (pers. comm., Geoffrey Kitchener, February/March 2018).

Sheldwich The BSBI Database and the Kent \& Medway Biological Records Centre have a record from January 2011; the host tree has been checked by the original recorder, determined to be lime ( Tilia sp.) and the record in both databases will be revised (pers. comm., Lliam Rooney, January 2018).

\section{Bedfordshire (v.c. 30)}

Wilstead Recorded in March 2006 by Bedfordshire Natural History Society as one medium clump of $V$. album on Quercus. Location checked in February 2018 but no $V$. album was seen on the trees (pers. comm., Jackie Ullyett, Bedfordshire and Luton Biodiversity Recording and Monitoring Centre).

\section{Monmouthshire (v.c. 35)}

Llanover South East Wales Biodiversity Records Centre (SEWBReC) has a record from January 2015 "'?oak tree with moderate clumps". A site visit in November 2018 confirmed the host as sycamore (Acer pseudoplatanus) and the original record will be revised (pers. comm., Jerry Lewis).

Mamhilad Titcombe (2018) refers to V. album on Q. palustris at the side of the A4042 in the Little Mill/Mamhilad area; this was a large bunch when recorded in August 2012 that has not been seen for the past couple of years (pers. comm., Colin Titcombe, December 2018). My visit in December 2018 with Colin Titcombe located the tree but no mistletoe was visible.

Penallt V. album on "red oak ( $Q$. borealis)" recorded by Colin Titcombe in February 2009 (SEWBReC). Reported on red oak (Q. rubra) (Titcombe, 2018).

Visits on 5 \& 16 December 2018: Mature $Q$. rubra growing on woodland edge. The tree is divided into two trunks almost from the base and the $\mathrm{dbh}$ cannot be measured in order to estimate age. The tree is in a line of red oaks and the two adjacent trees to the west were used as proxies with $\mathrm{dbh}$ of $56 \mathrm{~cm}$ and $59 \mathrm{~cm}$ at 1.3 $\mathrm{m}$ and estimated ages of around 60-70 years. A large straggly female bunch of V.album growing from multiple attachments to two upper branches on eastern side of trunk at approximately $7 \mathrm{~m}$ above ground level. 


\section{Worcestershire (v.c. 37)}

Great Malvern Recorded in a garden in SO74 in April 2008 "On Quercus rubra, more plants on similar trees in back garden (no access)" (pers. comm., John Day, August 2017).

Visits on 5 October \& 14 November 2017: Healthy, mature $Q$. rubra with a spreading crown growing in a hedgerow between a road and a private garden. The $\mathrm{dbh}$ is $80 \mathrm{~cm}$ at $1.3 \mathrm{~m}$ and the estimated age is $80-100$ years. Around six to seven female bunches and six to seven bunches assumed to be male ranging in size from large to small growing on branches at various heights from approximately $2 \mathrm{~m}$ above ground level to the upper parts of the tree. One bunch of what appeared to be dead V. album attached to a dead branch.

Huddington Recorded in March 2002 in SO95 "Large clump 3.5m up at junction at first main branch. Host juvenile tree approximately $7 \mathrm{~m}$ high and $0.47 \mathrm{~m}$ girth breast height" (pers. comm., John Day, August 2017).

Visit on 5 October 2017: Healthy, young $Q$. rubra growing in a hedgerow. The $\mathrm{dbh}$ is $31 \mathrm{~cm}$ at $1.3 \mathrm{~m}$ and the estimated age is $30-40$ years. Three large female bunches growing on branches at approximately $2 \mathrm{~m}$ and $3 \mathrm{~m}$ above ground level.

\section{Worcestershire (v.c. 37) \& Shropshire (v.c. 40)}

Bewdley Three historical reports on the north bank of the Dowles Brook at Bewdley were noted by Box (2000). A visit to the location in December 1996 found that there was no V. album present on this Quercus tree. Another visit in July 2017 confirmed the absence of $V$. album on this Quercus and on the very old pollarded Quercus opposite on the south bank of Dowles Brook. The location of the Quercus on the north bank was ascribed by Box (2000) to Worcestershire (v.c. 37) although it should be Shropshire (v.c. 40) following a close examination of the boundary between the two vice counties (the vice-county boundary tool http://www.cucaera.co.uk/grp/ on the BSBI website www.bsbi.org/maps-and-data).

\section{Staffordshire (v.c. 39)}

Arley Rea (1923) reports V. album on Q. rubra at Arley Castle. A report of $V$. album on one $Q$. rubra in Worcestershire by Maskew (2014) is based on data from a field meeting of the Wyre Forest Study Group to Arley Castle in January 2013 (pers. comms., John Hawksford, August 2017 and Brett Westwood, September 2017). Arley Castle is in the administrative county of Worcestershire but in v.c. 39 Staffordshire. My visits in November 2017 and February 2018 found no V. album on the $Q$. rubra at the reported locations.

\section{Shropshire (v.c. 40)}

Hughley My visit in January 2018 to the location (National Grid Reference SO 565966) of a field named as 'Mizzletoe Oak' on the map redrawn by HDG Foxall in 1977 from the 1839 tithe map and apportionment of Hughley parish in Shropshire (held by Shropshire Archives, Shrewsbury) found that the hedges have been altered and that no V. album was growing on the nearby Quercus trees.

\section{Nottinghamshire (v.c. 56)}

Wallingwells Under the heading 'Unknown locations', Box (2000) noted a report of three V. album plants on Quercus seen by Thomas Knowlton in August 1765 on the estate of .... White Esq. at Watling Wells (Dillwyn 1843) but this location could not be identified. Further research revealed an earlier account by Thomas Knowlton in a letter dated 20 January 1741 of $V$. album growing on Quercus that refers to Walling Wells (Henrey 1986), now known as Wallingwells, near Worksop. 
Enquiries of Carlton in Lindrick Parish Council and Woodsetts Local History Society in 2017 and my visit to one potential location in February 2018 produced no positive results.

\section{South-west Yorkshire (v.c. 63)}

Sheffield V. album reported growing on a young planted Quercus in February 2017 (Sheffield Biological Records Centre). Tree confirmed as Q. palustris from leaves in October 2017 (pers. comm., Michael Senkans, Parks \& Countryside Service, Sheffield City Council).

Visit on 20 January 2018: Young Q. palustris growing in a park. The dbh is 26 $\mathrm{cm}$ at $1.3 \mathrm{~m}$ and the estimated age is around 30 years (26-33 years). One female bunch of $V$. album with berries growing on top of a lower branch in the angle with the trunk at approximately $3 \mathrm{~m}$ above ground level.

\section{Discussion}

A further four Quercus trees parasitised by V. album (Fig. 2) have been identified during 2017 and 2018 in addition to the eleven parasitised trees recorded by Box (2000) between 1996 and 1998. Of these original eleven trees, one has been felled (Putley) and one has lost the branch supporting $V$. album (Stretton Sugwas). There were more bunches of $V$. album growing on the trees at Bredwardine, Leintwardine and Windsor than were reported in 2000. There are now thirteen Quercus trees parasitised by $V$. album in Britain.

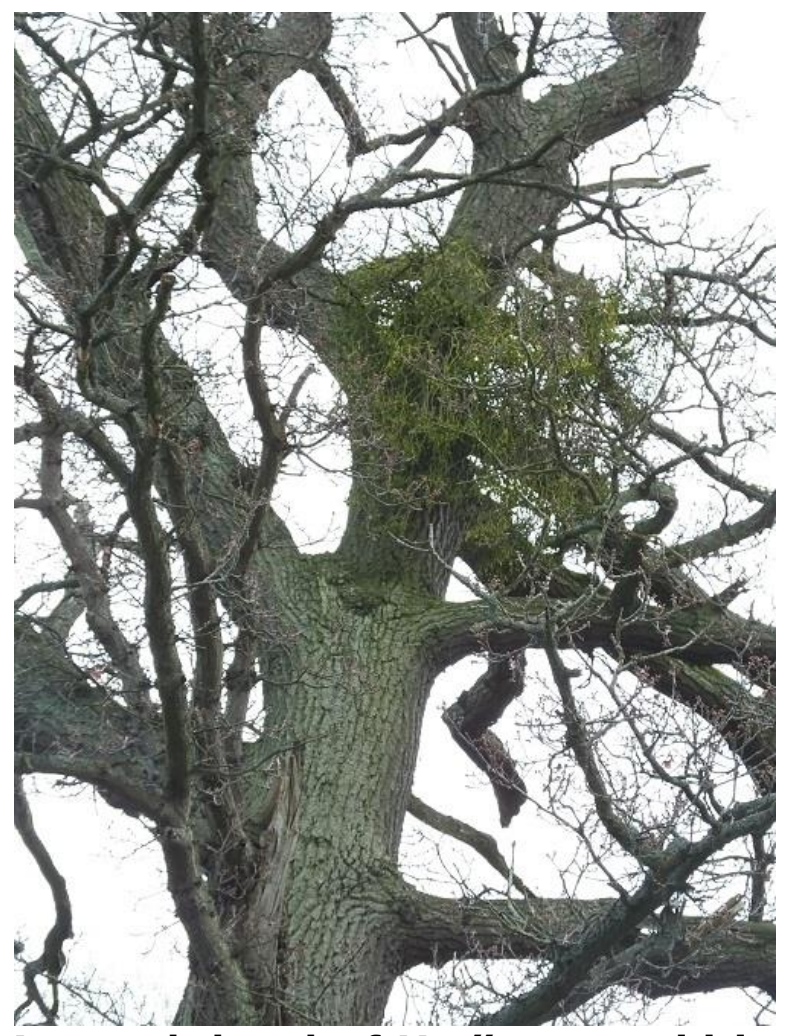

Figure 2. A straggly bunch of $V$. album parasitising $Q$. robur

The four recently recorded Quercus trees with $V$. album are growing in open situations (hedgerow, woodland edge, urban park, garden) which is consistent with those reported by Box (2000). The lower end of the age range of the original set of eleven trees ( 90 to 400 years) has been reduced to around 30 years, at least for red 
oaks, because of the new records at Huddington and Sheffield. The age of the $V$. album cannot be reliably estimated and the date of initial parasitism is unknown.

Viscum album is dioecious. Box (2000) reported that the V. album on three Quercus trees (Brampton Bryan, Gwehelog, Windsor) was recorded as 'probably male' because of the absence of berries in visits during November to February. There were no V. album berries visible on the tree at Gwehelog in November 2017 and the $V$. album is once again assumed to be male. However, berries were clearly visible on various parts of the V. album growing on Quercus at Brampton Bryan and at Windsor in November 2017, although no berries were visible on the previous visits to the Quercus trees at Brampton Bryan (December 1996, December 1998) and at Windsor (January 1997, November 1998) (Box 2000). This suggests that the $V$. album plants at both Brampton Bryan and Windsor are female but may lie at sufficient distance from the nearest male $V$. album that pollination does not always occur.

The V. album on the Quercus at Deerfold is notable because it has a very long recorded history. Bull (1869) includes a sketch of a bunch of $V$. album on a tree without leaves in March 1869 together with a description of it growing on a main stem of the tree after it has bifurcated; Anon. (1930) reports the $V$. album growing in the same location; a record from the national Biological Records Centre states "Extinct c. 1963"; Tonkin (1984) reported that the V. album was no longer there; Box (2000) recorded a bunch of $V$. album in 1996 on the west side of the western of the two main trunks which divided at about $6.5 \mathrm{~m}$ above ground level; there was a report by Jonathan Briggs of no visible V. album in February 2011 (https://mistletoematters.wordpress.com/2011/02/25/mistletoe-oaks-revisited/); my visits in November 2017 and February 2018 found no bunch of V. album but there were at least two short mature stems with clean cut ends and three small, young growths (Fig. 3) growing in the same position on the trunk as that depicted by Bull (1869). $V$. album has been recorded since 1869 growing in the same position on one of the two main stems or trunks of this tree, but the $V$. album was not present as a bunch around 1963, in 1984, in 2011 and was only present as small plants in winter 2017/18. Natural processes may have been involved (such as death or being blown off in a storm), but the recent evidence of cut ends to the main stems strongly suggests that the $V$. album was harvested by humans. $V$. album regrows as adventitious shoots from endophytic haustoria (Harley, 1863, page 185; Zuber, 2004, pages 182-183). The past reports of an absence of $V$. album may have been due to small, young regrowths not being visible from the ground.

Full descriptions of the locations of Quercus with V. album are not given in this paper because there have been financial offers to reveal such locations, especially on indigenous oaks ( $Q$. robur and $Q$. petraea). $V$. album is claimed to be an alternative therapy for cancer (for example, Mistletoe Therapy UK, http://www.mistletoetherapy.org.uk/) and is one of the most widely studied complementary and alternative medicine therapies for cancer (for example, National Cancer Unit, USA, https://www.cancer.gov/aboutcancer/treatment/cam/patient/mistletoe-pdq). V. album has been tested extensively as a treatment for cancer, but randomised controlled trials fail to show benefit (Ernst 2006). 


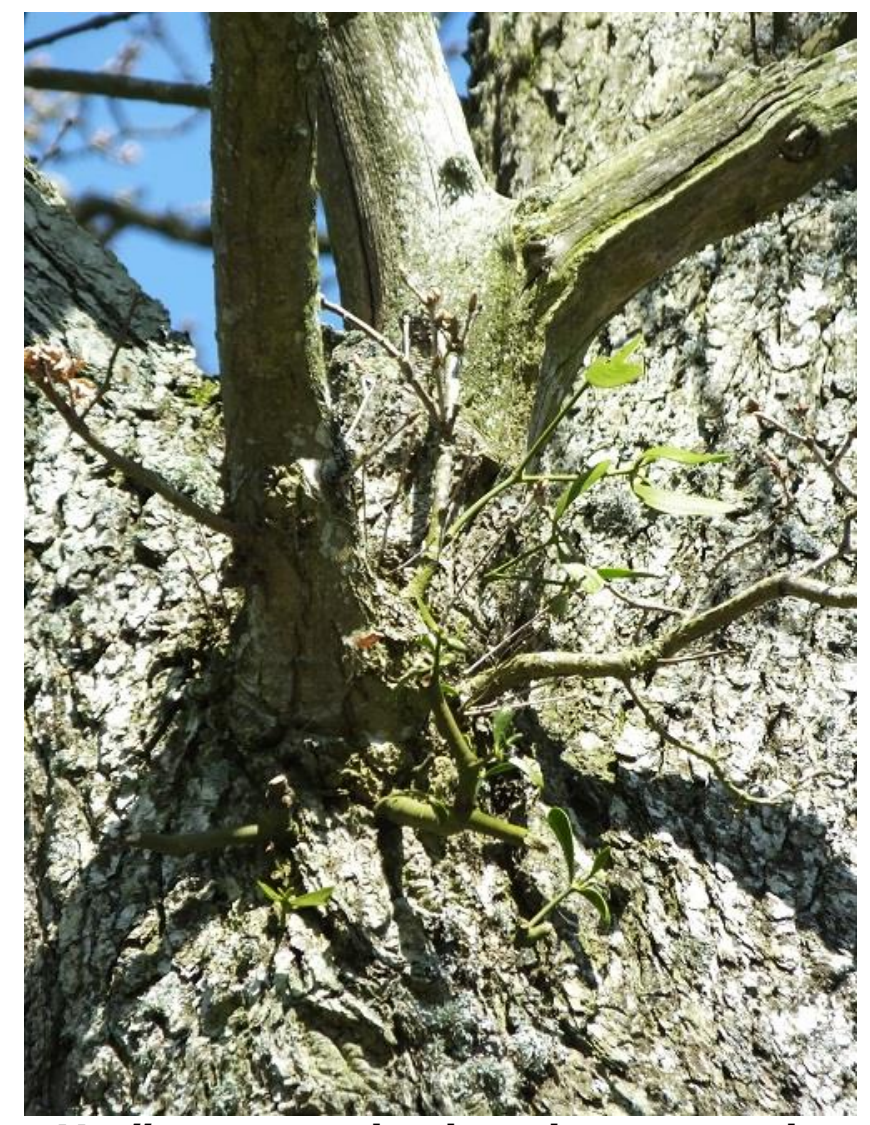

\section{Figure 3. Mature $V$. album stems that have been cut and small adventitious shoots on the Deerfold tree}

Quercus trees supporting V. album mainly occur in and around Herefordshire in the core of the current and past distribution of V. album in Britain (National Biodiversity Network Atlas

https://spatial.nbnatlas.org/?q=Isid\%3ANBNSYS0000003624; Briggs, 2011, page 24, Fig. 1; Perring 1973, page 143, Fig. 7). This geographical distribution has not yet been fully explained although climatic factors are considered to be very important in the distribution of V. album (Iversen, 1944; Perring, 1973; Briggs, 1991; Zuber, 2004). It is interesting to note that this core area is associated with the river basin district of the lower part of the river Severn (Environment Agency, 2016, page 12 \& Fig. 1) and this apparent association would merit further investigation.

The results of the 2017/18 survey of V. album parasitising Quercus accord with the conclusion of Box (2000), based on field data from 1996-1998 and reports in the 19th and early 20th centuries, that there is a population of between ten and twenty Quercus trees with $V$. album in Britain. This population appears to be relatively stable over time with some losses of host trees (or branches) with $V$. album and gains from the parasitism of new Quercus trees.

\section{Acknowledgements}

I am very grateful to Dr. Konrad Urech (Verein für Krebsforschung, Arlesheim, Switzerland) for many useful exchanges of information about mistletoe on oaks in Britain and Europe. The involvement of local records centres through ALERC and the assistance of the BSBI and the County Recorders have been of great assistance and a source of new records. I am grateful to Alex Lockton \& Sarah Whild (Shropshire 
Botanical Society) for new information on V. album on Quercus in Shropshire. Michael (Ziggy) Senkans (Parks \& Countryside Service, Sheffield City Council and Sheffield Biological Records Centre) drew my attention to the new record for Sheffield and provided associated information. John Day provided the initial information on additional locations in Worcestershire at Huddington and Great Malvern. Elaine Wright (SEWBReC), Steph Tyler (BSBI joint County Recorder, Monmouthshire), Elsa Wood (BSBI joint County Recorder, Monmouthshire) and Colin Titcombe provided information about V.album on Quercus at Penallt and Mamhilad. David Griffiths provided information about $V$. album on Quercus in Herefordshire in 2017 and supplied Figs. 2 \& 3. I am grateful to Wikimedia Commons for Fig. 1.

\section{References}

Anon. 1930. Second field meeting. Tuesday, June $24^{\text {th }}, 1930$. Deerfold Forest and Wigmore. Transactions of the Woolhope Naturalists Field Club 1930-1932, pages xvii-xx, published 1933.

Box, J.D. 2000. Mistletoe Viscum album L. (Loranthaceae) on oaks in Britain. Watsonia, 23: 237-256.

Briggs, J. 2011. Mistletoe - a review of its distribution, conservation and insect associates. British Wildlife, 23: 23-31.

Bull, H. G. 1869. Remarkable plants in Deerfold Forest. Transactions of the Woolhope Naturalists Field Club 1869, illustration facing page 15 \& pages 1516, published 1870.

Bull, H. G. 1907. The mistletoe in Herefordshire. Transactions of the Woolhope Naturalists Field Club 1852-1865, pages 312-347. [A reprint of the early volumes of the Transactions with footnotes and postscript added to the paper originally published in 1864].

Dillwyn, L. 1843. Hortus Collisonianus: an account of the plants cultivated by the late Peter Collinson Esq. FRS. Swansea: Privately published.

Ernst, E. 2006. Mistletoe as a treatment for cancer. British Medical Journal, 333: 1282-1283. [online]. [Accessed 6 April 2018]. Available at: http://www.bmj.com/content/bmj/333/7582/1282.full.pdf

Environment Agency 2016. Severn river basin district: Part 1 river basin management plan. Environment Agency, Bristol. [online]. [Accessed 6 April 2018]. Available at:

https://www.gov.uk/government/uploads/system/uploads/attachment data/file /501290/Severn RBD Part 1 river basin management plan.pdf

Evelyn, J. 1664. Sylya, or a discourse of forest-trees. $1^{\text {st }}$ ed. London: John Martin.

Frochot, H., Grazi, G. \& Urech, K. 1994. Sensibilité au gui du chêne rouge d'Amérique en France. In: Timbal, J., Kremer, A., Le Goff, N. \& Nepveu, G., eds. Le Chêne Rouge d'Amérique, pages 387-398 \& 504-511. Paris: Institut National de la Recherche Agronomique.

Grazi, G. \& Urech, K. 1983. La susceptibilité des chénes, des ormes et des mélèzes au gui (Viscum album L.). Revue Scientifique du Bourbonnais, pages 6-12.

Harley, J. 1863. On the parasitism of mistletoe (Viscum album). Transactions of the Linnean Society of London, 24: 175-196 and three separate plates. [The paper was read in March 1863 and printed in Volume 24, part 2, published in 1864]. [online]. [Accessed 6 April 2018]. Available at:

https://www.biodiversitylibrary.org/item/88071\#page/220/mode/1up 
Henrey, B. 1986. No ordinary gardener: Thomas Know/ton, 1691-1781. Chater, A.O., ed., pages 190-191. London: British Museum (Natural History).

Iversen, J. 1944. Viscum, Hedera and Ilex as climate indicators. Geologiska Föreningens i Stockholm Föhandlingar, 66: 463-483.

Loudon, J. C. 1838. Arboretum et Fruticetum Britannicum, Volume 3, page 1831. London: Longman, Orme, Brown, Green \& Longmans.

Maskew, R. 2014. The Flora of Worcestershire, page 377. Privately published by Roger Maskew.

Nicholson, C. 1932. The mistletoe and its hosts. The Gardeners' Chronicle, pages 102-104, 145-146.

Perring, F. 1973. Mistletoe. In: Green, P. S., ed. Plants wild and cultivated, pages 139-145. London: Botanical Society of the British Isles.

Ramm, H., Urech, K., Scheibler, M \& Grazi, G. 2000. Cultivation and development of Viscum album L. In: Büssing, A., ed. Mistletoe; the genus Viscum, pages 75-94. Amsterdam: Academic Publishers.

Ray, J. 1677. Catalogus Plantarum Angliae, et Insularum Adjacentium, $2^{\text {nd }}$. ed. page 307. London: John Martyn.

Rea, C. 1923. Appendix to the Botany of Worcestershire, pages 60-61. Transactions of Worcestershire Naturalists' Club, Volume VIII, Part 1, 1923. [The Viscum album account appeared in the fourth section of the Appendix that was issued with the Transactions of Worcestershire Naturalists' Club, Volume VIII, Part 1, 1923. The full and final version of the Appendix was published in 1931 with the Transactions of Worcestershire Naturalists' Club, Volume VIII, 1923-1931].

Titcombe, C. 2018. New opportunities for the growth and expansion of Mistletoe in Gwent. Gwent-Glamorgan Recorders' Newsletter, Issue 19, page 3. [online]. [Accessed 12 November 2018]. Available at: http://www.sewbrec.org.uk/gwent-glamorgan-recorders-newsletter/g-grecorders-newsletter-issues.page

Tonkin, M. 1984. The Wigmore Inclosure Act and Award, 1810-1828. Transactions of the Woolhope Naturalists Field Club, 44: 283-300.

Tubuef, K. von 1923. Monographie der Mistel. München und Berlin: Verlag Oldenbourg.

Urech, K. 2008. Misteltragende Eichen - Häufigkeit und geographische Verbreitung in Frankreich. Mistilteinn, 8: 28-39.

White, J. 1998. Estimating the Age of Large and Veteran Trees in Britain. Edinburgh: The Forestry Commission.

Withering, W. 1796. An Arrangement of British Plants, $3^{\text {rd }}$. ed. Birmingham: M. Swinney.

Zuber, D. (2004) Biological flora of Central Europe: Viscum album L. Flora, 199: 181203. [online]. [Accessed on 6 April 2018]. Available at:

https://www.sciencedirect.com/journal/flora

Copyright retained by author(s). Published by BSBI under the terms of the Creative Commons Attribution 4.0 International Public License. 